\title{
Intracranial high-resolution vessel wall imaging in CADASIL
}

Eric D. Goldstein, MD, Jennifer J. Majersik, MD, MS, and Scott McNally, MD, PhD

Neurology ${ }^{\circledR}$ 2020;94:1040-1041. doi:10.1212/WNL.0000000000009588

Figure 1 Intracranial vessel wall MRI of cerebral autosomal dominant arteriopathy with subcortical infarcts and leukoencephalopathy

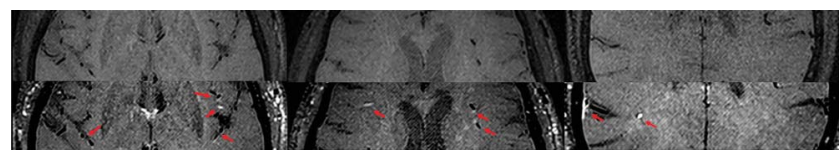

Top row showing T1 precontrast axial images compared with bottom row showing T1 postcontrast mural enhancement of the subcortical and leptomeningeal arteries. Note cortical venous mural enhancement in the bottom right pane. Arrows indicate intramural enhancement.

A 64-year-old man with cerebral autosomal dominant arteriopathy with subcortical infarcts and leukoencephalopathy (CADASIL) (heterozygous, c.544C $>\mathrm{T}$; p.Arg182Cys) underwent an intracranial high-resolution black-blood protocoled vessel wall MRI (vwMRI). Intramural patchy gadolinium enhancement in the subcortical and leptomeningeal arteries and veins was noted, consistent with the histopathologic findings of CADASIL (figures 1 and 2). ${ }^{1,2}$ We hypothesize that vwMRI allowed for an in vivo view of the vasculopathy intrinsic to CADASIL. Pending investigation of larger cohorts, this imaging technique may provide a novel mechanism for understanding CADASIL progression and pathogenesis, as well as potentially serving as

Figure 2 Baseline white matter burden

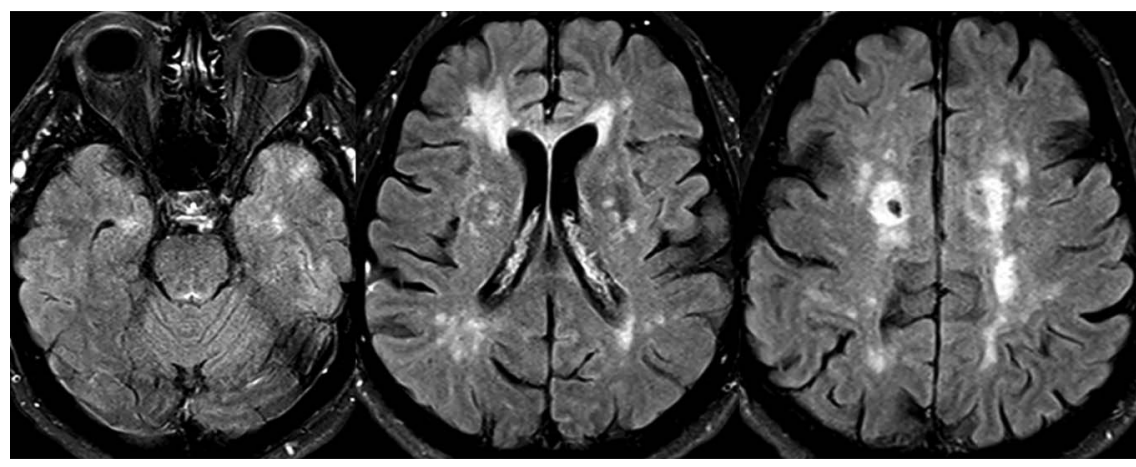

Axial fluid-attenuated inversion recovery sequences show $\mathrm{T} 2$ subcortical white matter hyperintensities consistent with cerebral autosomal dominant arteriopathy with subcortical infarcts and leukoencephalopathy. Images provided for comparison.

\section{Correspondence}

Dr. Goldstein

eric.goldstein@hsc.utah.edu

From the Departments of Neurology (E.D.G., J.J.M.) and Neuroradiology (S.M.), University of Utah, Salt Lake City.

Go to Neurology.org/N for full disclosures. Funding information and disclosures deemed relevant by the authors, if any, are provided at the end of the article. 
a biomarker in future disease modification trials and aiding in the differential diagnosis for interpreting clinicians.

\section{Study funding}

No targeted funding reported.

\section{Disclosure}

The authors report no relevant disclosures. Go to Neurology. org/N for full disclosures.

Appendix Authors

\begin{tabular}{lll}
\hline Name & Location & Contribution \\
\hline Eric D. & University of & Design and conceptualization, \\
Goldstein, & Utah, Salt Lake & $\begin{array}{l}\text { drafted manuscript for intellectual } \\
\text { content }\end{array}$ \\
MD & City & \\
\hline
\end{tabular}

Appendix (continued)

\begin{tabular}{lll}
\hline Name & Location & Contribution \\
\hline $\begin{array}{l}\text { Jennifer J. } \\
\text { Majersik, MD, } \\
\text { MS }\end{array}$ & $\begin{array}{l}\text { University of } \\
\text { Utah, Salt Lake } \\
\text { City }\end{array}$ & $\begin{array}{l}\text { Drafting and revision } \\
\text { of manuscript for } \\
\text { intellectual } \\
\text { content }\end{array}$ \\
\hline $\begin{array}{l}\text { Scott } \\
\text { McNally, MD, } \\
\text { PhD }\end{array}$ & $\begin{array}{l}\text { Utahiversity of Salt Lake } \\
\text { City }\end{array}$ & $\begin{array}{l}\text { Drafting and revision } \\
\text { of manuscript for } \\
\text { intellectual } \\
\text { content }\end{array}$ \\
\hline
\end{tabular}

\section{References}

1. Coupland K, Lendahl U, Karlström H. Role of NOTCH3 mutations in the cerebral small vessel disease cerebral autosomal dominant arteriopathy with subcortical infarcts and leukoencephalopathy. Stroke 2018;49:2793-2800.

2. Rafalowska J, Fidzianska A, Dziewulska D, Podlecka A, Szpak GM, Kwiecinski H. CADASIL or CADVaSIL? Neuropathology 2004;24:16-20.

\section{The AAN is at Your Side}

When you're in the office, the AAN is at your side. The AAN is your \#1 resource to support you and your care team. Whether it's resources to help you and your staff provide the best care for your patients, ensure proper reimbursement, or maximize practice performance, the AAN is at your side. Access these resources today at AAN.com/view/practiceresources.

\section{Visit the Neurology ${ }^{\circledR}$ Resident \& Fellow Website}

Click on Residents \& Fellows tab at Neurology.org.

Now offering:

- Neurology ${ }^{\circledR}$ Resident \& Fellow Editorial team information

- "Search by subcategory" option

- E-pearl of the Week

- RSS Feeds

- Direct links to Continuum ${ }^{\circledR}$, Career Planning, and AAN Resident \& Fellow pages

- Recently published Resident \& Fellow articles

- Podcast descriptions

- Blogs by Editors and Resident \& Fellow team members

f Find Neurology ${ }^{\circledR}$ Residents \& Fellows Section on Facebook: facebook.com/AANResidentsAndFellows

Follow Neurology ${ }^{\circledR}$ on Twitter: @GreenJournal \#NeurologyRF

(0) Find Neurology ${ }^{\circledR}$ Residents \& Fellows Section on Instagram: @aanbrain \#NeurologyRF 


\title{
Neurology
}

\author{
Intracranial high-resolution vessel wall imaging in CADASIL \\ Eric D. Goldstein, Jennifer J. Majersik and Scott McNally \\ Neurology 2020;94;1040-1041 Published Online before print May 19, 2020 \\ DOI 10.1212/WNL.0000000000009588
}

This information is current as of May 19, 2020

\section{Updated Information \& Services}

References

Subspecialty Collections

Permissions \& Licensing

Reprints including high resolution figures, can be found at:

http://n.neurology.org/content/94/23/1040.full

This article cites 2 articles, 0 of which you can access for free at: http://n.neurology.org/content/94/23/1040.full\#ref-list-1

This article, along with others on similar topics, appears in the following collection(s):

MRI

http://n.neurology.org/cgi/collection/mri

Other cerebrovascular disease/ Stroke

http://n.neurology.org/cgi/collection/other_cerebrovascular_disease_st roke

Stroke in young adults

http://n.neurology.org/cgi/collection/stroke_in_young_adults

Information about reproducing this article in parts (figures,tables) or in its entirety can be found online at:

http://www.neurology.org/about/about_the_journal\#permissions

Information about ordering reprints can be found online:

http://n.neurology.org/subscribers/advertise

Neurology ${ }^{\circledR}$ is the official journal of the American Academy of Neurology. Published continuously since 1951, it is now a weekly with 48 issues per year. Copyright (O) 2020 American Academy of Neurology. All rights reserved. Print ISSN: 0028-3878. Online ISSN: 1526-632X.

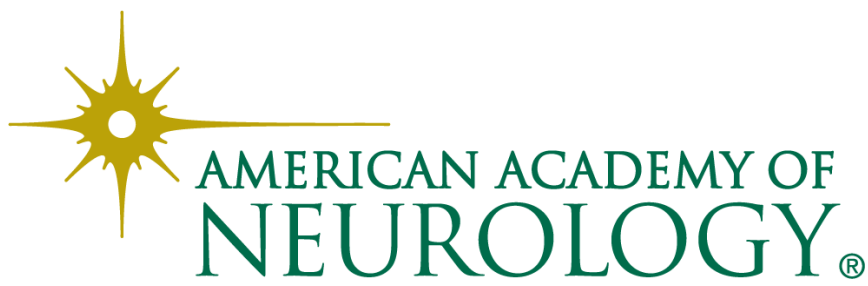

